\title{
THE MEAT-MARKET AT CORINTH (1 CORINTHIANS 10:25)
}

\author{
David W.J. Gill
}

\section{Summary}

The presence of a meat market at Corinth may be ascertained by a pair of Latin inscriptions. They record the gifts of the building by a member of the local social elite probably in the Augustan period. A third Greek graffito sometimes associated in modern literature with the macellum is irrelevant to the debate. The layout of the Corinthian market can be deduced from the similiar situations in the Roman empire.

\section{Introduction}

The identification of the meat-market (macellum) at Corinth has long been of interest to scholars as it was here that Christians were buying food which had been offered in sacrifice. ${ }^{1}$ Paul in his discussion of food offered to idols

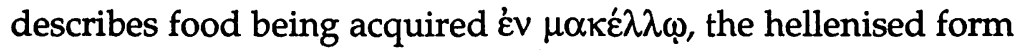
of the Latin macellum. The Greek form of the word had been noted from Greek inscriptions in Asia Minor and Greece itself. 2

\section{The Macellum Inscriptions}

During the American excavations at Corinth, there was some anticipation that remains of the structure would be found. F.J. de Waele, for example, argued that the macellum was probably situated in the area of the peribolos of Apollo beside the Lechaion Road. ${ }^{3}$ Part of the excitement had been aroused

${ }^{1}$ H.J. Cadbury, 'The macellum of Corinth', JBL 53 (1934) 134-41.

2Cadbury, 'Macellum' 135. See also BCH 10 (1886) 420; 17 (1893) 261 no. 45; 20 (1896) 126. Such buildings appeared in the province of Achaia from the reign of Augustus onwards; at Sparta the Greek loan-word

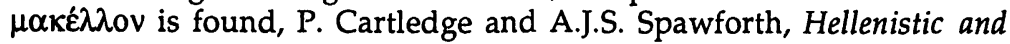
Roman Sparta: A Tale of Two Cities (London, Routledge 1989) 130. 3F.J. de Waele, 'A Roman market at Corinth', AJA 34 (1930) 453-4. 
by the discovery of a fragmentary marble inscription in 1898 which seemed to refer to the structure.4

The inscription reads:

Q(uintus) Co[r]nelius [.] f(ilius) [A]em(ilia) Secundus [et]

Maec[ia $Q$ (uintus)] $f(i l i a)$ vxor [eius] [.] [Cornelius Secundus M]a[e]cianus f(ilius) $Q$ (uintus) Corn[elius]

Secu[nd]us $f$ [Co]rn[elia Secunda $f$ eius vxor $Q$ (uintus) M]a[e]ci Q(uintus) 1(ibertus) Cleogen[is]

macellv[m ------------ cum ------] et pi[scario ------]

inea loc [-----o---]

West, followed by Kent, took this pair of inscriptions to refer to a separate Macellum Piscarium. The crucial penultimate lines of the inscriptions read:

macellu[m --- cum ---]et pi[scario ---]

[macellum ---cum pi]scario et bilac ---

However this interpretation has been challenged. 5 Nabers has argued that it is unlikely that the Cornellii would provide two separate buildings which would serve the same function. As other inscriptions from macella include the phrase macellum cum in order to list features of the complex such as tholoi, it seems likely that the macellum at Corinth was equipped with additional elements which included the provision for fish. The rarity of the words do not allow for a more exact translation. The inscription would thus read:

Quintus Cornelius Secundus, son of [---], of the tribe Aemilia, and his wife Maecia, daughter of [Quintus], his son [--- Cornelius Secundus] Maecianus, his son Quintus Cornelius Secundus, his [daughter] Cornelia [Secunda, who is the wife of Quintus] Maecius

4The fragment reads MACELLV. Other parts of the same inscription, along with a parallel dedication were published in A.B. West, Latin Inscriptions 1896-1926 Corinth 8:2, (Cambridge (Mass.), American School of Classical Studies 1931) nos. 124-5, with a further fragment found in the South Basilica being added by J.H. Kent, The inscriptions 1926-1950 Corinth 8:3, (Princeton (NJ), American School of Classical Studies) no. 321, along with changes to West, op. cit., no. 124. These inscriptions are presumably to what Fee refers, although without reference: 'a Latin inscription of the macellum in Corinth has been discovered, undoubtedly the very one Paul is referring to here'. G.D. Fee, The First Epistle to the Corinthians (Grand Rapids, Eerdmans 1987) 480 n. 20.

${ }^{5} \mathrm{~N}$. Nabers, 'A note on Corinth VIII, 2, 125', AJA 73 (1969) 73-4. 
Cleogenes the freedman of Quintus (Maecius), [built (?)] the meatmarket [---] along with [---] and facilities for fish [----].

The inscription itself seems to be Augustan in date, and thus the gift of a macellum to the newly established colony would be one of several buildings presented by members of the local social elite. 6 The presence of parallel benefactor inscriptions on the same building is not unknown.7

\section{The Loukios Inscription}

Cadbury in his discussion of the Latin inscription had noted that $\mathrm{O}$. Broneer had been excavating alongside the Lechaion Road in one of the possible locations for the macellum. Further excitement concerning the location of the building was aroused in April 1936 when an inscribed block was found in the cryptoporticus of the South Basilica. This had been a wall block from the South Stoa (adjoining the forum) and over traces of Greek stucco was a coat of Roman plaster into which were scratched two lines of Greek text. These two lines were thought to read:

\section{$\triangle O Y K I O C$ \\ $\Lambda \mathrm{AN}[\mathrm{IO}] \mathrm{C}$ \\ Loukios the butcher}

Such a reading would have confirmed Cadbury's suggestion about the possibility of discovering the macellum in Broneer's trench, and thus the following year Broneer announced the find and drew attention to its apparent relevance to the debate about the macellum at Corinth.8 After the initial excitement, Broneer seems to have reassessed the evidence and realised that the second word need not be completed as a banausic, but rather that it could also be a name. Thus when he came to

\footnotetext{
${ }^{6}$ For the phenomenon of gifts of macella by members of the social elite, see D. Perring, 'Spatial organisation and social change in Roman towns', in J. Rich and A. Wallace-Hadrill (ed.), City and Country in the Ancient World (London, Routledge 1991) 288.

7Nabers, op. cit., 73.

${ }^{8} \mathrm{O}$. Broneer, 'Studies in the topography of Corinth at the time of St. Paul', Archaiologike Ephemeris (1937) 125-133. See also L. Robert, REG 53 (1940) 210.
} 
publish the inscription in the monograph on the South Stoa, he had revised his opinion supplying the text as: ${ }^{9}$

\author{
$\Lambda$ OrKIOC \\ KAN[IO]C \\ Loukios Kanios
}

Broneer realized that this inscription was the Greek version of a Latin name, Lucius Canius.10 A further possibility, is to replace the nomen Kanios by the toponym Kanaios. Thus the inscription would read 'Loukios from the city of Canae (in Aeolis)'.11 Finally, the second word could be providing a 'nickname' for Lucius, such as (skinny') кóv[ð̌ß]os or $\kappa \alpha ́ \mu[\pi]$ os ('monster').12 Although archaeologists and epigraphists are aware of the changed reading of the inscription, Broneer's original text occasionally continues to be cited by those involved in New Testament studies. 13

\title{
IV. The Form of Macella
}

Although the macellum at Corinth has yet to be identified with certainty-there is a possibility that it will be found in the area around the Lechaion Road14 - the type of building is well known from other cities of the Roman empire. 15 The one at Pompeii was located at the north-east corner of the forum and dates to $150-100$ BC. 16 It consisted of colonnaded shops around the walls of the building. In the centre of the central open space was a tholos in which there was a pool, a quantity

${ }^{9}$ O. Broneer, The South Stoa and its Roman Successors Corinth 1:4, (Princeton (NJ), American School of Classical Studies at Athens 1954) 101, pl. 25, 2.

${ }^{10}$ This is how the inscription is published by Kent, op. cit., 139-40, no. 353.

11See W. Leaf, BSA 22 (1916-18) $37 \mathrm{ff}$.

${ }^{12}$ As suggested by Kent, op. cit.

${ }^{13}$ E.g. John McRay, Archaeology and the New Testament (Grand Rapids, Baker Book House 1991) 326-7.

${ }^{14}$ See J. Wiseman, 'Corinth and Rome I: 228 BC - AD 267', ANRW II 7.1 (1979) 526-7. One macellum lies to the north of Temple Hill.

${ }^{15} \mathrm{~N}$. Nabers, 'The architectural variations of the macellum', Opuscula Romana 9 (1973) 173-6. The possibilities for Corinth are discussed at $p$. 176. See also C. du Ruyt, Macellum, marché alimentaire des Romains (Louvain-la-Neuve, 1983).

${ }^{16}$ Arnold and Mariette de Vos, Pompeo, Ercolano, Stabia: Guida archeologiche Laterza 11 (Rome and Bari, Laterza 1982) 43-6. 
of fish scales was found, suggesting that this space was probably used for the sale of fish. In addition to stalls, there were a range of other rooms in the building, including shrines of the emperor. The walls were decorated with lavish paintings, such as that showing Argos and Io.17 Another macellum, dating to $8 \mathrm{BC}$, was at Lepcis Magna. 18 This was equipped with two octagonal tholo in the central courtyard. The appearance of a macellum is known through the image of the Macellum Magnum built by Nero on the Caelian Hill at Rome which was used on a dupondius. ${ }^{19}$ These show the tholos which has both an upper and a lower storey, and the building stood on a podium reached by a flight of steps. Given that the Corinthian macellum had the facility for fish within the complex, it is likely that it would have been a colonnaded building perhaps with a tholos in the central area. ${ }^{20}$

17 R. Ling, Roman Painting (Cambridge, CUP 1991) 130, fig. 133.

${ }^{18} \mathrm{~N}$. Degrassi, 'Il mercato romano di Leptis Magna', Quaderni di archeologia della Libia 2 (1951) 27-70. See also: J. Carter, 'Civic and other buildings', in I.M. Barton (ed.), Roman Public Buildings. Exeter Studies in History 20 (Exeter, University of Exeter 1989) 59-61, fig. 22; J.B. Ward-Perkins, Roman Imperial Architecture (Hardmondsworth, Pelican 1981) 374. For the inscriptions: R.G. Goodchild, 'Two monumental inscriptions of Lepcis Magna', Papers of the British School at Rome 18 (ns 5, 1950) 72-7.

${ }^{19} \mathrm{H}$. Mattingly, Coins of the Roman Empire in the British Museum (London, British Museum Publications rev. ed. 1976) nos. 191-7 (Rome) and 335-7 (Lugdunum); G. Fuchs, Architekturdarstellungen auf römischen Münzen der Republik und der frühen Kaiserzeit (Berlin, 1969) 46, figs 133-6. See also J.S. Rainbird \& F.B. Sear, and J. Simpson, 'A possible description of the Macellum Magnum of Nero', Papers of the British School at Rome 39 (1971) 40-6.

20J.B. Ward-Perkins, ('From Republic to Empire: Reflections on the early provincial architecture of the Roman West, JRS 60 (1970) 15-16, 18 fig. 19,) notes that the North Market at Corinth was of the Pompeian type without a tholos. 